\title{
Theoretical basis on Determinants of Corporate Bond Spreads
}

\author{
Jie MinHuang \\ Shenzhen Institute of Information Technology \\ 2188 Longxiang Boulevard, Longgang District, Shenzhen Shenzhen City \\ People's Republic of China, 086-518172 huang_jiemin819@126.com
}

\begin{abstract}
This paper analyzes the theoretical basis of the relevant papers. First, the meaning and connotation of corporate bond yield spreads to define the difference between corporate bonds and corporate bonds; secondly, analyzed the determinants of corporate bond yield spreads, including: macroeconomic factors, capital market factors, individual factors of corporate bonds; and then introduces research methods of corporate bond yield spreads, including GARCH and ARCH methods, time series analysis, panel data fixed effects model, state space model and Kalman filter method.
\end{abstract} rates

Keywords-determinants; bond spread; capital factors; gdp;

\section{DEFINING CORPORATE BOND YIELD SPREADS}

\section{A. connotation of corporate bonds}

Tools of debt borrowed by private companies or public companies use according to the Commercial Press published "in English and Chinese Securities Investment Dictionary", refers to corporate bonds.

Chinese presence corporate bonds and corporate bonds of two credit bonds. About China bond market corporate bonds and corporate bonds, there are three different views, some people think corporate bonds and US municipal bonds is similar to the same corporate bonds and corporate bonds in Europe and America; some people think that corporate bonds include corporate bonds issued by the state-owned enterprises project bonds; Some people believe that they are different, corporate bonds can be included in corporate bonds, which is relativistic thinking.

In fact, it is different in the following aspects, one, many corporate bonds guaranteed bonds issued by local governments, such as the city to vote bonds and the like. Second, corporate bonds to raise funds according to project needs, different European and American corporate bonds. Third, from the bond issuance and regulatory point of view, corporate debt and project construction is closely related to corporate bonds issued by the Development and Reform Commission approval. The corporate bonds issued by the SFC approval, the exchange market transactions.

From the above analysis it shows that the scope of corporate bonds and corporate bonds can not be divided according to the extension division of the company and the enterprise. According to the current bond market supervision and transactions, corporate bonds and corporate bonds coexist, both approving and different regulators, trading venues and counterparties are also different.
Corporate bond research object for the Shanghai Stock Exchange and Shenzhen Stock Exchange trading, via the Commission approved the issuance of these bonds, issuers of listed companies. The bonds are mostly short and medium term. Bond credit rating is relatively high. Issuers widely distributed range of industries, covering almost all sectors, with a certain representation.

\section{B. connotation yield spreads}

Early corporate bond yield spread has been called by many scholars credit spreads, it is assumed that risk-free Treasury bonds, corporate bonds yield to maturity is higher than the same period some of the risk-free government bonds yield to maturity. Investors face is mainly credit risk, corporate bond yield spreads to some extent reflects the size of the company's credit risk profile.

Early scholars adopt corporate bond yield spread measure the size of the company's credit risk, while investors expected loss is the main measure of credit risk. So, in this assumption, the expected loss on the value should be equal to the yield corporate bond spreads. But recently, some scholars empirical analysis found that the expected loss of corporate bond yield spreads over much smaller. The shorter the term of the bond, the higher the credit rating, expected loss accounts for corporate bond yield spreads smaller proportion.

Therefore, many scholars of the difference between the corporate bond yield spreads and expected loss were analyzed. The results show that corporate bond yield spread not only affected the credit risk is also affected by exchange rates, inflation, GDP growth, the broad money supply, tax, systemic risk, idiosyncratic volatility, liquidity risk and other factors. Elton (2001) the corporate bond yield spread is divided into: taxes, expected losses and residual three [1]. Delianedis and Geske (2001) showed that corporate bond yield spreads mainly caused by tax recoveries, market risk and liquidity risk [2]. Driessen (2005) that the corporate bond yield spread the default risk, tax, systemic risk and liquidity risk caused by [3]. Some scholars believe that corporate bond yield spreads including spreads and default spreads remaining residual spreads caused by unexpected losses, default spreads caused by the expected loss [4].

This article will be expected inflation, exchange rates, the broad money supply, GDP growth rate, idiosyncratic volatility, liquidity risk, tax, risk and other risks caused by the system, the same release period, the same expiration date and the yields of corporate bonds It is defined as the spread between corporate bond yield spreads (corporate 
bond spread). It is the object of study, hereinafter referred to as the yield spread, or spread or risk premium.

\section{ANALYSIS ON DETERMINANTS OF CORPORATE BOND SPREADS}

Wherever Times is specified, Times Roman or Times New Roman may be used. If neither is available on your word processor, please use the font closest in appearance to Times. Avoid using bit-mapped fonts if possible. TrueType 1 or Open Type fonts are preferred. Please embed symbol fonts, as well, for math, etc.

\section{A. Macroeconomic Factors}

1) GDP growth (GDP) and the Purchasing Managers Index (PMI)

Black, Kirkwood and Williams (2013) analysis of the Australian corporate bonds, the analysis takes into account the growth rate of gross domestic product (GDP) and other macroeconomic factors [5]. Raedels (1990) found that the use Purchasing Managers Index (PMI) macroeconomic forecast ahead of other predictors of seven months [6]. Kauffman (1999) on the purchasing managers 'index (PMI) index systematic and comprehensive analysis and proved Purchasing Managers' Index (PMI) indicators six months ahead of other indicators forecast economic development situation changes [7]. Recently, Lindsey and Pavur (2005) attempted to predict the turning point Purchasing Managers 'Index (PMI) indicators, they analyzed the samples for a longer time, and proposed using regression analysis Purchasing Managers' Index (PMI) of inflection, and their research methods Carter and Ellram's (2003) is similar to [8-9]. Larrain (2007) using regression and neural network forecasting Purchasing Managers' Index (PMI), study results showed that short-term interest rates can be predicted 10 months Purchasing Managers' Index (PMI) for the change, the article focused on the purchasing managers' index (PMI) as a predictor of . Among the many variables, the Purchasing Managers Index (PMI) may be a good predictor of the real inventory, indicate purchasing managers index (PMI) can predict changes in inventories 8 months [10]. Zhangxue $\mathrm{Ru}$ (2010) analyzed the growth rate of gross domestic product (GDP) impact on credit spreads [11] in the determinants of credit spreads change a text.

Scholars from the analysis showed that gross domestic product growth (GDP) and the Purchasing Managers Index (PMI) are the macroeconomic development in an important predictor, but purchasing managers index (PMI) predicted more time-sensitive. Some foreign scholars have used the gross domestic product growth (GDP) as macroeconomic indicators, analyze its impact on corporate bond yield spreads. Based on the study on the basis of foreign scholars, representatives select both indicators of macroeconomic factors.

2) Rates

Clare et al. (2000) analysis found that if the dollar-real exchange rate, the euro will have a positive bond spreads [12]. KatiusciaManzoni (2002) using the mark against the pound sterling exchange rate expressed appreciation or depreciation, he believes that if the appreciation of sterling, the overseas bond issuer to repay the credit increase, so credit spreads increase [13]. Sun Ke (2010) analyzed the impact of the RMB against the US dollar corporate bond credit spreads, exchange rates and corporate bonds and found a significant negative correlation between credit spreads [14]. JAHJAH (2013) analyzed the impact of exchange rate policies on developing countries bonds, he found that the national fixed exchange rate of their issuance of bonds with a higher interest rate [15].

Based on the above analysis, this paper against the dollar as one of the factors of macroeconomic indicators, based on the above analysis, if the RMB against the US dollar exchange rate, the devaluation of the yuan outside, help export-dependent manufacturing business development, corporate bond yields, the interest rate differential relatively lower. This paper will analyze the impact on the corporate bond yield spreads.

3) broad money supply (M2)

Davies (2004) found that market factors and economic environmental factors better than the company's individual factors explain the corporate bond yield spreads, Krainer (2004), Tsuji (2005), Christensen (2008) [16-17].

Alessandrini (1999), Huang and Chen (2007) found that monetary policy is an important determinant of corporate bond yield spreads [18-19]. Beckworth, Moon, Toles (2010) with long-term currency neutral conditions vector autoregression method to verify the impact of monetary policy on corporate bond yield spread default risk, liquidity risk and risk aversion affected. He found that the impact of monetary policy can indeed explain corporate bond yield spreads in large part. Studies suggest that the impact of monetary policy by influencing the default risk, risk aversion and liquidity premium to influence corporate bond yield spread, monetary policy shocks and corporate bond yield spreads reverse change [20].

These studies show that when the government implemented loose monetary policy, namely to increase the broad money supply (M2), the good economic environment, enterprises are facing bankruptcy risk of default is reduced, on the contrary, increase. According to research scholars, this paper this variable as one of the important macroeconomic indicators, analyze its impact on corporate bond yield spreads.

\section{4) Consumer Price Index}

Sun Ke (2010) will be the consumer price index (CPI) as one of macroeconomic factors, which indicates inflation by analyzing its impact on corporate bond credit spreads, inflation is found in one of the important factors [14].

In this paper, scholars, based on the consumer price index (CPI) as the inflation factor, it will be as a macroeconomic factors, to measure the impact on the corporate bond yield spreads.

5) producer price index

He Liping, Fan et al. (2008) in the consumer price index and producer price index: Who who led one paper analyzes the linkage between the producer price index (ppi) and the consumer price index between the industrial products price index? As an important measure of macroeconomic indicators [21].

When the producer price index (ppi) rises, the industrial enterprises in the relevant industry chain costs rise, companies face increased risk, so the company to improve the probability of default.

This paper will be the basis of the existing literature Industrial price index (ppi) as an important indicator of 
macroeconomic analysis of its impact on corporate bond yield spreads.

\section{6) corporate goods price index trading}

Zhangcheng Si (2010) in the long-run equilibrium price and currency-driven --- Forced research article in the business of commodity trading prices (cgpi) on the middle and lower price transmission mechanism of price transmission mechanism as intermediate links, which represents corporate wholesale products Reproduction of the price level, analysis of the impact on price, currency and other macroeconomic [22].

When the corporate goods price index transactions (cgpi) rise, upstream firms increased costs will increase Forced whole industry chain costs, the company faced increased risk, thus increasing corporate bond yields. This paper will analyze the impact of corporate goods price index transactions (cgpi) corporate bond yield spreads.

7 ) industrial sales output value and industrial added value

Sun Ke (2010), the growth rate of the industrial production index as one of macroeconomic factors, analyze their impact on corporate bond credit spreads [14].

In this paper will be the basis of its research and the industrial added value of industrial sales output value as independent variables, they are an important indicator of macroeconomic factors, analyze its impact on corporate bond yield spreads. Because the industrial sales output value and industrial added value increased, indicating that the economy in good condition, reduce the probability of bankruptcy, thus reducing the corporate bond yield spread.

\section{B. Capital Market Factors}

Merton (1974) in a recent study suggested that holders of corporate bonds can be seen as a risk-free bonds held by investors, he sold a put option to the holders of the company's stock, while increasing volatility When the value of put options increases, increase revenue stockholders, bondholders simultaneously reduce income [23]. Volatility and option value related, so the company's debt is the total value of the company volatility, including the idiosyncratic volatility and systems market volatility or volatility. This is important, because idiosyncratic volatility and market volatility change direction very different. Campbell et al. (2001) confirmed the Merton's view, noting in particular that since the mid-1970s, idiosyncratic volatility on the rise, and the market volatility experienced temporary fluctuations, but there is no increasing trend [24]. Campbell and other studies have shown that in the past few decades in the 20th century or the late 1990s, idiosyncratic volatility will drive down the price of corporate bonds to raise the company's stock price.

Some scholars are from the volatility of the stock and bond returns were analyzed in terms of dispersion. Campbell and Taksler (2003) analyzed the impact of stock volatility on corporate bond yields. They used data late 1990s proved idiosyncratic volatility and the credit rating company level can be interpreted as a large part of corporate bond yields change. Recent studies have found that stock returns and analysts predict the dispersion of earnings-related, they think asset prices reflect more optimistic point of view of investors, because the stock market restrictions [25] on the short sale. Guntay and Hackbarth (2010) analyzed whether there is the same situation in the bond market. They control the bond credit rating, the company rating and the macroeconomic variables in the study, they found that companies with high earnings forecast dispersion bonds than similar companies have higher credit spreads. The study also has short selling restrictions. They interpret this as: earnings dispersion that the future cash flows of the corporate bond market uncertainty [26].

Cai (2008) further found that idiosyncratic risk bonds predictable bond excess returns. He used 1996--2005 years of data found that corporate bond excess return volatility excess returns associated with corporate bonds. Bonds and bond volatility related to income than large stocks qualities associated risks. In addition, bond volatility and idiosyncratic risk is a predictor of the excess return of corporate bonds. He found that the volatility of corporate bond contains a time-varying.

Some scholars on the basis of existing studies found that idiosyncratic risk spreads have a major impact on the company's bond yields. Gomez-Puig (2009) analyzed the impact of system factors and idiosyncratic risk factors on the corporate bond yield spreads. He used panel data for research. Analysis of the domestic and international risk factors. Analysis shows that idiosyncratic risk factor compared to systemic risk factors explained more corporate bond yield spread. Gemmill and Keswani (2011) analysis of why the corporate bond yield spread much larger than expected loss given default. System factors on the corporate bond yield spread is small, although the impact will decline in value is taken into account. Instead, they found that corporate bond yield spreads and idiosyncratic volatility factors are closely related, not only closely related to the idiosyncratic volatility stocks, bonds idiosyncratic volatility and idiosyncratic risk bonds worth more relevant. Bonds idiosyncratic volatility can explain corporate bond yield spreads, because it not only reflects the distribution of the company's value, but also on behalf of the liquidity risk. Left-leaning nature of the distribution of the bond value at risk on behalf of corporate bonds. The results confirmed the above view, they were used 1997-2004 years of data and 2005--2009 years of data, the sample includes the economic crisis. They believe that corporate bond yields great because it contains extreme fear of the loss of investors' risk premium. Hibbert et al. (2011) analyzed the determinants of the US corporate bond market credit spreads diurnal variation. They select investment-grade bonds and high-yield bonds, the study found trait factors of the stock market, bonds, stock market system factors and factors of corporate bond yield spreads diurnal variation affected. They found that stock market volatility to increase the corporate bond yield spread has a positive effect. The results show that the company's stock returns and bond issuers yield spread reverse changes.

The influence of the above documents idiosyncratic volatility and the volatility of corporate bond yield spreads, studies show that idiosyncratic volatility spreads have a significant impact on corporate bond yields. Based on existing research on the analysis of the stock index and bond index and the stock idiosyncratic volatility, idiosyncratic volatility affecting bond yields on corporate bond spreads. 


\section{REFERENCES}

[1] Elton E, Gruber M, Agrawal D, Mann C. Explaining the rate spread on corporate bonds[J]. Journal of Finance, 2001, 56: 247277.

[2] Delianedis G., Geske R. The components of eorporate credit spreads: default, reeovery, tax, jumps, liquidity and market faetors [M]. Finance, 2001, 1-39.

[3] Driessen J. Default Event Risk Priced in Corporate Bonds? [J]. The Review of Financial Studies, 2005, 18: 165-195.

[4] Black S., Joshua K., Williams T. A history of Australian corporate bonds[J]. Australian Economic History Review, 2013, 53(3): 292 317.

[5] Raedels A. Forecasting the MAPM Purchasing Managers' Index[J] Journal of Supply Chain Management, 1990, (15): 34-39.

[6] Kauffman R.G. Indicator Qualities of the NAPM Report On Businesss[J]. The Journal of Supply Chain Management, 1999, (35): 29-37.

[7] Lindsey M.D., Pavur R.J. As the PMI Turns: A Tool for Supply Chain Managers[J]. Journal of Supply Chain Management, 2005, (1): 30-39.

[8] Carter C.R., Ellram L.M. Thirty-five Years of the Journal of Supply Chain Management: Where HaveWe Been and Where Are We Going?[J]. Journal of Supply Chain Management, 2003, 39(2): 27-39.

[9] Larrain M. The PMI, the T-Bill and Inventories: A Comparative Analysis of Neural Network and Regression Forecasts[J]. The Journal of Supply Chain Management, 2007, (1) : 39-51.

[10] Clare AD, Oozeer MC, Priestley R, et al. Modeling the Risk Premium on Eurodollar Bonds $[\mathrm{J}]$. The Journal of Fixed Income, 2000, 9: 61-73.

[11] Katiuscia M.Modeling Credit Spreads:An Application to the Sterling Eurobond Market[J]. International Review of Financial Analysis, 2002, 11: 183-218.

[12] Jahjah M. Exchange Rate Policy and Sovereign Bond Spreads in Developing Countries[J]. Journal of Money, Credit and Banking, 2013, 45(7): 1276-1300.
[13] Davies A. Credit spread modeling with regime switching techniques[J]. The Journal of Fixed Income, 2004, 14: 36-48.

[14] Krainer J. What determines the credit spread?[J]. FRBSF Economic Letter, 2004, 36: 1-3.

[15] Tsuji C. The credit-spread puzzle[J]. Journal of International Money and Finance, 2005, 24: 1073-89.

[16] Christensen J. The corporate bond credit spread puzzle[J]. FRBSF Economic Letter, 2008, 10: 1-3.

[17] Alessandrini F. Credit risk, interest rate risk, and the business cycle[J]. The Journal of Fixed Income, 1999, 9: 42-53.

[18] Huang Y, Chen C R. The effect of Fed monetary policy regimes on the US interest rate swap spreads[J]. Review of Financial Economics, 2007, 16: 375-99.

[19] Beckworth D, Moon K P, Toles J H. Monetary policy and corporate bond yield spreads[J]. Applied Economics Letters, 2010, 17: 1139-1144.

[20] Campbell J., LettauY. M. Have individual stocks become more volatile? An empirical explanation of idiosyncratic risk[J]. Journal of Finance, 2001, 56: 1-43.

[21] Campbell J, Taksler G. Equity volatility and corporate bond yields[J]. Journal of Finance, 2003, 58: 2321-2350.

[22] Güntay L, Hackbarth D. Corporate bond credit spreads and forecast dispersion [J]. Journal of Banking \& Finance, 2010, (34):2328 2345.

[23] Cai N. Corporate Bond Returns and Volatility[J]. The Financial Review, 2008, 43: 1-26.

[24] G' omez-Puig M. Systemic and Idiosyncratic Risk in EU-15 Sovereign Yield Spreads after Seven Years of Monetary Union[J]. European Financial Management, 2009, 15(5) : 971-1000.

[25] Gemmill G, Keswani A. Downside risk and the size of credit spreads[J]. Journal of Banking \& Finance, 2011, 35: 2021-2036.

[26] Hibbert A. M. Credit Spread Changes and Equity Volatility: Evidence from Daily Data[J]. The Financial Review, 2011, 46: 357-383. 